\title{
The WD repeats of Tup1 interact with the homeo domain protein $\alpha 2$
}

\author{
Kelly Komachi, ${ }^{1,3}$ Michael J. Redd, ${ }^{1,3}$ and Alexander D. Johnson ${ }^{1,2}$ \\ ${ }^{1}$ Department of Biochemistry and Biophysics, ${ }^{2}$ Department of Microbiology and Immunology, University of California, \\ San Francisco, California 94143 USA
}

\begin{abstract}
Tup1 and Ssn6 transcriptionally repress a wide variety of genes in yeast but do not appear to bind DNA. We provide genetic and biochemical evidence that the DNA-binding protein $\alpha 2$, a regulator of cell-type-specific genes, recruits the Tup1/Ssn6 repressor by directly interacting with Tup1. This interaction is mediated by a region of Tup1 containing seven copies of the WD repeat, a 40 amino acid motif of unknown function found in many other proteins. We have found that a single WD repeat will interact with $\alpha 2$, indicating that the WD repeat is a protein-protein interaction domain. Furthermore, a fragment of Tup1 containing primarily WD repeats provides at least partial repression in the absence of Ssn6, suggesting that the repeats also mediate interaction between Tup1 and other components of the repression machinery.
\end{abstract}

[Key Words: Homeo domain; WD repeat; transcriptional repression]

Received September 15, 1994; revised version accepted October 18, 1994.

Cells have evolved a variety of mechanisms for turning genes off when they are not needed. In the budding yeast Saccharomyces cerevisiae one repression system is remarkable for its involvement in regulating a wide variety of genes. Two proteins, Ssn6 and Tup1, are required for the repression of at least five independently regulated sets of genes: the a cell-specific genes and the haploidspecific genes, the glucose-repressed genes, the hypoxic genes, and the DNA damage-inducible genes (Mukai et al. 1991; Keleher et al. 1992; Trumbly 1992; Zitomer and Lowry 1992; Elledge et al.1993).

Both Ssn 6 and Tupl are members of extended protein families. Ssn 6 contains 10 copies of the tetratricopeptide repeat or TPR (Schultz and Carlson 1987). Tupl also contains a repeated sequence that was first identified in $\beta$-transducin, the WD repeat (Fong et al. 1986). Seven WD repeats have been identified within Tup1 (Williams and Trumbly 1990; see also results of this work). This motif is $\sim 40$ amino acids in length and contains a highly conserved tryptophan-aspartate or WD sequence. Proteins with WD repeats are involved in a wide variety of processes, including gene repression, signal transduction, secretion, RNA splicing, and progression through the cell cycle (for reviews, see Duronio et al. 1992; van der Voorn and Ploegh 1992).

The function of WD repeats is not known, although it has been suggested that they mediate protein-protein interactions. The function of the WD repeats of Tup1 remains obscure. Deletion of a single repeat results in the same phenotype as a complete deletion of the gene (Williams and Trumbly 1990). However, expression of

\footnotetext{
${ }^{3}$ These authors contributed equally to this work.
}

the amino-terminal 200 amino acids of Tup1 lacking all of the WD repeats is able to function for glucose repression as well as function partially for hypoxic gene repression (Tzamarias and Struhl 1994).

How do Tupl and Ssn 6 regulate diverse sets of genes? It has been proposed that Ssn6/Tupl is a general repressor in yeast, recruited to genes by specific DNA-binding proteins (see Fig. 1). These DNA-binding proteins would then be subject to regulation in response to the appropriate signals (Keleher et al. 1992). Several lines of evidence support this model. First, Ssn 6 and Tupl are found associated in a protein complex (Williams et al. 1991). Second, both LexA-Ssn 6 and LexA-Tupl fusion proteins can repress transcription of a test promoter possessing a LexA binding site (Keleher et al. 1992; Tzamarias and Struhl 1994). Third, DNA-binding proteins that are required for repression and that bind to sequences upstream of the regulated genes have been identified for all but one of the sets of genes known to be regulated by Ssn6/Tup1: $\alpha 2$ for a-specific genes and haploid-specific genes, Migl for glucose-repressed genes, and Roxl for hypoxic genes (Johnson and Herskowitz 1985; Nehlin and Ronne 1990; Balasubramanian et al. 1993).

One of the best characterized of this group of DNAbinding proteins is the $\alpha 2$ protein. Budding yeast exists as three different cell types, a cells, $\alpha$ cells, and a/ $\alpha$ diploid cells. $\alpha 2$ is expressed in $\alpha$ cells, where it is required for the repression of a-specific genes, and in $a / \alpha$ diploid cells, where it is required for the repression of both a-specific genes and haploid-specific genes. The a-specific genes are constitutively expressed in a cells because this cell type does not contain the $\alpha 2$ gene. In $\alpha$ cells $\alpha 2$ binds cooperatively with the $\mathrm{Mcml}$ protein to a DNA se- 


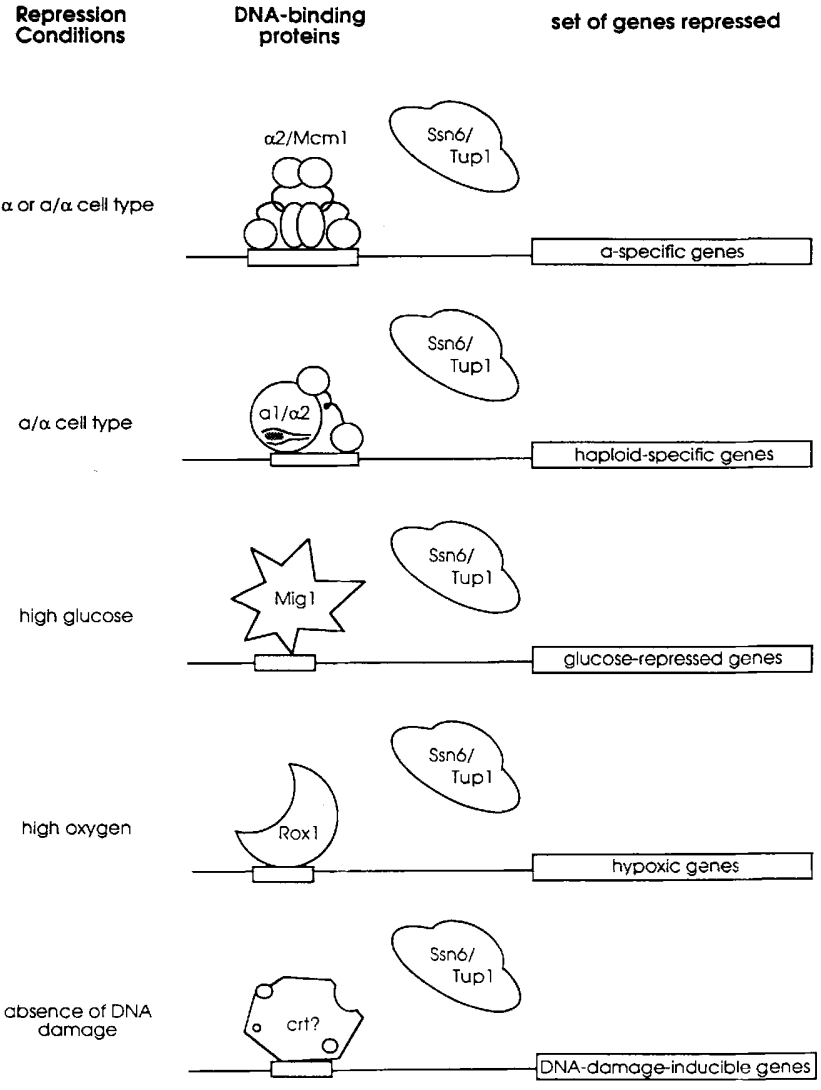

Figure 1. Ssn 6 and Tupl are required for repression of many different genes. Ssn 6 and Tup1 mediate repression of the five sets of genes listed at right. Repression of each particular set of genes also requires specific upstream sequences and the DNAbinding protein or proteins indicated to the left of the each set of genes.

quence called the a-specific gene operator located upstream of each a-specific gene (for review, see Johnson 1992). Once bound to the operator $\alpha 2$ directs the Ssn $6 /$ Tupl-dependent repression of the gene. Placing an $\alpha 2$ operator upstream of other yeast genes-CYC1, TRP1, $U R A 3$ and GAL1-brings them under the control of $\alpha 2$ directed repression, indicating that the repression is not specific for particular activators (Johnson and Herskowitz 1985; Roth et al. 1990; K. Komachi and M. Redd, unpubl.). Occupancy of the operator by $\alpha 2$ is not sufficient to bring about repression. In vivo dimethyl sulfate (DMS) footprinting of the a-specific gene STE6 demonstrated that $\alpha 2$ is able to bind the STE6 operator in the absence of Ssn6 but is unable to bring about repression (Keleher et al. 1992).

These results show that $\alpha 2$ carries out two functions: (1) It binds to operators upstream of specific genes; and (2) it directs the Ssn6/Tupl dependent repression of those genes. $\alpha 2$ possesses a homeo domain located at the carboxyl terminus that is responsible for its DNA binding. The portion of $\alpha 2$ involved in directing repression has not been clearly identified, although the amino terminus has been implicated (Hall and Johnson 1987). In this paper we examine, both genetically and biochemically, the link between $\alpha 2$ and the Ssn6/Tup1 repressor. We show that $\alpha 2$ binds to Tupl and that this interaction is mediated by the WD repeats of Tupl.

\section{Results}

Isolation of $\alpha 2$ mutants defective in repression but not DNA binding

To better understand how $\alpha 2$ directs repression after it has bound to its operator, we isolated mutants of $\alpha 2$ defective in repression but competent for DNA binding. To facilitate the identification of such mutants, we exploited the fact that $\alpha 2$ binds cooperatively to its operator with an activator, Mcm1 (Keleher et al. 1989), and designed a screen in which repression-defective mutants would activate transcription by helping $\mathrm{Mcml}$ bind DNA. Our screen was based on the following observations: (1) In the absence of $\alpha 2, \mathrm{Mcm} 1$ binds to the center of the wild-type operator and activates transcription (Bender and Sprague 1987; Keleher et al. 1988; Passmore et al. 1989); (2) a mutant operator in which the Mcm1binding portion has been replaced by an unrelated sequence (the center-substituted operator) does not bind $\mathrm{Mcml}$ and does not activate transcription (Keleher et al. 1988); and (3) the cooperative interaction between $\alpha 2$ and $\mathrm{Mcm} 1$ allows formation of the $\alpha 2 / \mathrm{Mcml}$ complex on the center-substituted operator in the presence of high levels of $\alpha 2$ (C.A. Keleher and A.D. Johnson, pers. comm.). In principle, overexpression of an $\alpha 2$ mutant defective only in repression should activate transcription from the center-substituted operator by recruiting $\mathrm{Mcm} 1$ to the DNA.

A plasmid that overexpresses $\alpha 2$ was mutagenized and transformed into a yeast strain carrying a lac $Z$ reporter in which the upstream activating sequences have been replaced by the center-substituted operator. Transformants $(36,000)$ were screened for $\beta$-galactosidase activity, and 20 positives were picked. Of these 20,12 yielded plasmids that reproduced the original phenotype when reintroduced into the reporter strain. The 12 plasmids were sequenced and found to contain one of four point mutations, as summarized in Figure 2A. Two of the plasmids also contained silent mutations, and one of the plasmids bearing the thr 4 mutation had an additional Arg $\rightarrow$ Gly amino acid change at position 60 . Plasmids containing more than one mutation were not used in any of the subsequent work.

To further test the idea that the mutants we have isolated are defective in a repression function other than DNA-binding, we expressed each of the mutant proteins in bacteria. Using the gel-mobility shift assay, we found that the mutant proteins bind to the $\alpha 2$ operator both alone and cooperatively with $\mathrm{Mcml}$ in a manner indistinguishable from that of wild-type $\alpha 2$ (data not shown).

The $\alpha 2$ mutants are defective in repressing authentic a-specific genes

To show that the inability of the $\alpha 2$ mutants to repress is 
A

$$
\begin{array}{lc}
\begin{array}{l}
\text { amino acld } \\
\text { change }
\end{array} & \begin{array}{c}
\text { \# of } \\
\text { mutant plasmids }
\end{array} \\
\text { ile4 to thr4 } & 4 \\
\text { leu9 to phe9 } & 3 \\
\text { leu } 10 \text { to ser10 } & 2 \\
\text { gly71 to lys71 } & 3
\end{array}
$$

\begin{tabular}{|c|c|c|}
\hline MAT $\alpha$ & CV13 ( $2 \mu \mathrm{m}$ vector $)$ & $0.8 \pm 0.3$ \\
\hline MAT $\alpha$ & MATa $2 / C V 13$ & $\leq 0.1$ \\
\hline MAT $\alpha$ & MATo2lys $71 / \mathrm{CV} 13$ & $2.3 \pm 0.3$ \\
\hline MAT $\alpha$ & MATa 2 phe $/$ CV 13 & $5.0 \pm 1$ \\
\hline MAI $\alpha$ & $\mathrm{MAT} \alpha 2^{\text {thr } 4} / \mathrm{CV} 13$ & $34 \pm 10$ \\
\hline MAI $\alpha$ & MAT $2^{\text {ser }} 10 / C V 13$ & $53 \pm 3$ \\
\hline
\end{tabular}

$\begin{array}{lc}\text { C CELL TYPE } & \beta \text {-GALACIOSIDASE ACTIVIIY } \\ \text { MAIa } & 150 \pm 20 \\ \text { MAT } \alpha & 0.7 \pm 0.1 \\ \text { MAT } \alpha 2^{\text {lys } 71} & 75 \pm 7 \\ \text { MAT } \alpha 2 \text { pheq } & 120 \pm 30 \\ \text { MAT } \alpha 2^{\text {thr }} 4 & 100 \pm 10 \\ \text { MAT } \alpha 2^{\text {ser } 10} & 150 \pm 20\end{array}$

B

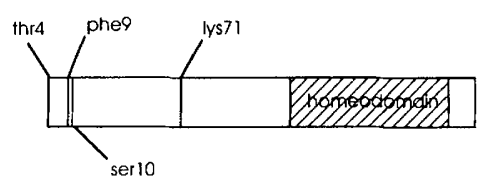

D CELL TYPE $\alpha 2$ PLASMID $\beta$-GALACTOSIDASE ACIIVITY
Figure 2. $\alpha 2$ Repression-defective $\mathrm{mu}$ tants. $(A)$ Summary of $\alpha 2$ mutations and the frequency with which they were isolated. $(B)$ Location of mutations relative to the homeo domain. $(C)$ Yeast strains differing only at the MAT locus (cell type) were assayed for $\beta$-galactosidase activity from an integrated $m f \alpha 2: 1 a c Z$ reporter. Each reported value is the average of three $\beta$-galactosidase assays. (D) A MAT $\alpha$ f $\alpha 2$ :lacZ strain was transformed with a high-copy mutant $\alpha 2$ plasmid and assayed for $\beta$-galactosidase activity. Each reported value is the average of three $\beta$-galactosidase assays performed on three individual transformants. not peculiar to transcription of the reporter used in our screen, we replaced the wild-type copy of $\alpha 2$ at the $M A T$ locus with each of the mutant copies in a strain carrying an $m f a 2: 1 a c Z$ reporter and examined the ability of the mutants to direct repression of this a-specific gene fusion. MFA2 encodes the mating pheromone, $\mathbf{a}$-factor and is normally repressed in $\alpha$ cells. As shown in Figure 2C, the $m f a 2: l a c Z$ reporter is expressed in a cells, repressed in $\alpha$ cells, and derepressed to various levels in mutant $\alpha$ cells. In addition, the mutant strains produce extracellular a-factor and barrier activity as determined by bioassay (Sprague 1991; data not shown) and hence must also express the a-specific genes STE6 and BAR1, which encode a pheromone export protein and the barrier protease, respectively (MacKay et al. 1988; McGrath and Varshavsky 1989|.

\section{The $\alpha 2$ mutations are dominant negative}

If the mutant proteins are defective in repression but not in binding to the operator with $\mathrm{Mcml}$, we expect these alleles to be dominant when the mutant proteins are overexpressed because they should bind to the operator and block access to wild-type $\alpha 2$. To test this prediction, we transformed high-copy plasmids containing the mutant $\alpha 2$ genes into a wild-type $\alpha$ strain carrying the mfa2:lacZ reporter and assayed the transformants for $\beta$-galactosidase activity. Results are summarized in Figure 2D. Each of the four mutant proteins caused derepression of the reporter, showing that all of the mutations are dominant negative for $\alpha 2$-mediated repression.

In summary, we believe we have isolated mutant versions of $\alpha 2$ that occupy the operator but fail to repress transcription of the a-specific genes. We refer to these mutant proteins as repression-defective mutants.

The dominance of some of the $\alpha 2$ mutants is suppressed by overexpression of Tup1

We speculated that the repression-defective mutants fail to interact with another protein of the repression complex, most likely Ssn6 or Tup1, both which are required for repression of the a-specific genes and have been proposed to interact with DNA-binding proteins (see Introduction). If this hypothesis is correct, we expected that increasing the concentration of Ssn6 or Tupl might offset the decreased affinity of the repression-defective mutants for these proteins and restore repression. We first tested whether overexpression of Ssn6 and/or Tup1 suppressed the inability of the $\alpha 2$ mutants to repress transcription by transforming strains carrying a chromosomal mata 2 mutation with high-copy plasmids bearing SSN6, TUP1, or SSN6 and TUP1 and monitoring the expression of an $m f a 2: 1 a c Z$ reporter. None of the plasmids restored repression in any of the strains (data not shown).

We next tested whether overexpression of Ssn6 and/or Tupl would suppress the dominance of the repressiondefective mutants. Because $\alpha 2$ binds its site as a dimer, the mutants can presumably exclude the wild-type protein from the operator by binding the site as either homodimers or heterodimers with wild-type $\alpha 2$. We reasoned that interaction of a heterodimer with the downstream protein might be restored at a concentration lower than that required for interaction with a mutant homodimer. Overexpression of Ssn6 and Tup1 from a high-copy plasmid, though unable to suppress the defect of cells expressing only the mutant forms of $\alpha 2$, does restore repression to an $m f a 2: 1 a c Z$ reporter in cells expressing both wild-type $\alpha 2$ and the dominant-negative forms of $\alpha 2$ (Fig. 3). Moreover, overexpression of Tup1 alone suppresses the dominance of the weaker mutants, suggesting that Tup1 might interact directly with $\alpha 2$ and that the mutants that we have isolated might be defective in binding to Tup 1 . We therefore set out to look for an interaction between $\alpha 2$ and Tup 1 in vitro.

\section{$\alpha 2$ binds to Tup1 in vitro}

To test the hypothesis that Tup 1 and $\alpha 2$ interact, we first fused the TUP1 gene to the glutathione $S$-transferase 


\begin{tabular}{|c|c|c|c|}
\hline CEL TYPE & $\alpha 2$ PLASMID & $\begin{array}{l}\text { SUPPRESSION } \\
\text { PLASMID }\end{array}$ & $\begin{array}{l}\text { B-GALACIOSIDASE } \\
\text { ACTIVITY }\end{array}$ \\
\hline MAT $\alpha$ & MATo2lys $71 / C V 13$ & YEP24 (2um URA 3 vector) & $2.5 \pm 0.5$ \\
\hline MAT $\alpha$ & MAT $\alpha 2^{l y s} 71 / C V 13$ & SSNG/YEp24 & $3.3 \pm 0.2$ \\
\hline MAT $\alpha$ & MAT $\alpha 2$ lys $71 / \mathrm{CV} 13$ & TUPI/YEp24 & $0.8 \pm 0.1$ \\
\hline MAT $\alpha$ & MAT $\alpha 2^{\text {lys } 71 / C V 13}$ & (SSNG+TUP1)/YEp24 & $0.9 \pm 0.3$ \\
\hline $\operatorname{MAT} \alpha$ & MATa2phe9/CV13 & YEp24 & $13.4 \pm 2.0$ \\
\hline MAT $\alpha$ & MAT $\alpha 2$ phe $9 /$ CV13 & SSNO/YEp24 & $22.0 \pm 8.9$ \\
\hline MAT $\alpha$ & MATa 2 phe $/ \mathrm{CV} 13$ & TUP1/NEp24 & $1.7 \pm 0.4$ \\
\hline MAT $\alpha$ & MAT $\alpha 2$ phe $9 / \mathrm{CV} 13$ & (SSNG+TUPI)/NEP24 & $0.9 \pm 0.1$ \\
\hline MAT $\alpha$ & MATa $2^{\text {thr } 4 / C V 13}$ & YEp24 & $47 \pm 5$ \\
\hline MAT $\alpha$ & MAT $\alpha 2^{\text {thr } 4 / C V 13}$ & SSNG/VEp24 & $46 \pm 13$ \\
\hline MAT $\alpha$ & MAT $22^{\text {thr } 4 / C V 13}$ & TUP1/NEP24 & $24 \pm 3$ \\
\hline MAT $\alpha$ & MAT $\alpha 2^{\text {thr } 4} / C_{C V 13}$ & (SSNO+TUP1)/YEP24 & $8.7 \pm 1.5$ \\
\hline MAT $\alpha$ & MAT $\alpha 2 \operatorname{ser} 10 / C V 13$ & Yep24 & $112 \pm 10$ \\
\hline MAT $\alpha$ & MAT $\alpha 2 \operatorname{ser} 10 / \mathrm{CV}_{13}$ & SSNG/YEp24 & $90 \pm 7$ \\
\hline MAT $\alpha$ & MAT $\alpha 2 \operatorname{ser} 10 / C V 13$ & TUP1/YEP24 & $73 \pm 3$ \\
\hline MAT $\alpha$ & MAI $\alpha 2^{\operatorname{ser} 10} / \mathrm{CV} 13$ & (SSNG+TUP1)/YEP24 & $23 \pm 3$ \\
\hline MATa & & YEp24 & $150 \pm 23$ \\
\hline MAIa & & SSNG/YEp24 & $155 \pm 15$ \\
\hline MATO & & TUP1/VEp24 & $160 \pm 10$ \\
\hline MATa & & (SSNG+TUP1)/YEP24 & $146 \pm 19$ \\
\hline
\end{tabular}

Figure 3. The dominance of the $\alpha 2$ mutants is suppressed by overexpression of Tupl and Ssn6. A MATa $m f \alpha 2: 1 a c Z$ strain was transformed with a high copy mutant $\alpha 2$ plasmid and a suppression plasmid and then assayed for $\beta$-galactosidase activity. The last set of assays shows that the suppression plasmids do not affect $\beta$-galactosidase expression in the absence of $\alpha 2$. Each reported value is the average of three $\beta$-galactosidase assays performed on three individual transformants.

(GST) gene and purified the fusion protein from Escherichia coli (GST-TUP1, Fig. 4A). The purified GSTTUP1 (Fig. 5A, lane 7) was then coupled to a column matrix through which bacterial extracts containing the $\alpha 2$ protein (lane 1) were passed. The flowthrough fractions contained most of the bacterial proteins but lacked $\alpha 2$, indicating that $\alpha 2$ was selectively retained on the column (lanes 18-22). The bound $\alpha 2$ protein was then eluted from the column by high salt (lane 4).

To determine which portion of Tupl is required for binding $\alpha 2$, we constructed two additional GST fusion proteins: GST-NTERM consisting of amino acids 1-253 of Tupl, and GST-CTERM, consisting of the remaining carboxy-terminal portion of Tupl fused to GST (Fig. 4A). $\alpha 2$ (again present in a bacterial extract) was specifically retained on the GST-CTERM column (Fig. 5A, lanes 1317) and was eluted from the column by high salt (lane 3). In contrast, $\alpha 2$ flowed through the column bearing the GST-NTERM protein (lanes 8-12), and salt elution yielded only a small fraction of the $\alpha 2$ loaded (lane 2). These results indicate that $\alpha 2$ binds specifically to Tup 1 and that the carboxy-terminal portion of Tup1 mediates this interaction.

The carboxyl terminus of Tupl contains the six WD repeats identified by Williams and Trumbly (Fig. 4A, labeled 2-7). To determine whether these repeats mediate the interaction with $\alpha 2$, we further subdivided Tupl into two more GST fusion proteins: the middle region consisting of amino acids 252-390 (GST-MID), and the WD region consisting of amino acids $420-713$ (Fig. 4A, GSTWD). Surprisingly, $\alpha 2$ bound to both GST-MID and GST-WD (data not shown; summarized in Fig. 4A). This result indicates that Tupl contains at least two separable $\alpha 2$-binding domains, one that is essentially a series of WD repeats, suggesting that a function of these repeats is binding $\alpha 2$.

\section{$\alpha 2$ binds to a single WD repeat}

Comparison of the portion of Tupl within the GST-MID fusion protein with the Tupl WD repeats revealed a region of similarity indicating that Tupl may have a seventh WD repeat. Amino acids $341-383$ of the middle portion of Tupl do not contain the highly conserved tryptophan-aspartate motif characteristic of the repeat, but do share significant sequence homology with the

A

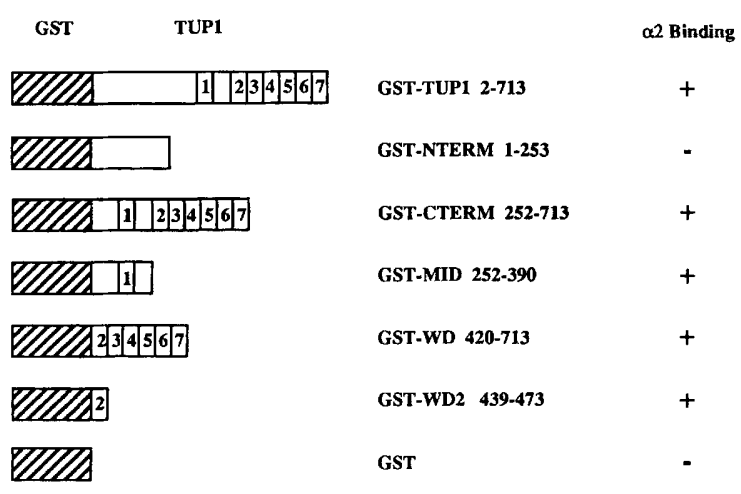

B

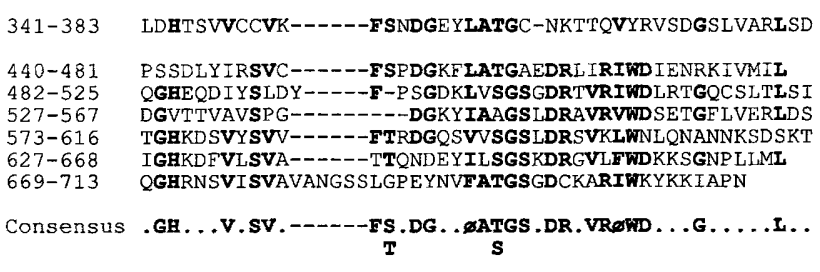

Figure 4. GST-TUP1 fusion proteins with a summary of $\alpha 2$ binding results and alignment of Tup1 WD repeats. $(A)$ The GST portion is represented by the hatched portion. The numbered boxes represent the WD repeats of Tup1. The amino acids of Tupl included in each fusion protein are indicated. $(B)$ Amino acids 341-383 aligned with the six WD repeats of Tupl. The alignment and consensus were made by hand. The dashes represent gaps, as the repeat lengths differ. In the consensus, ø represents hydrophobic residues. 


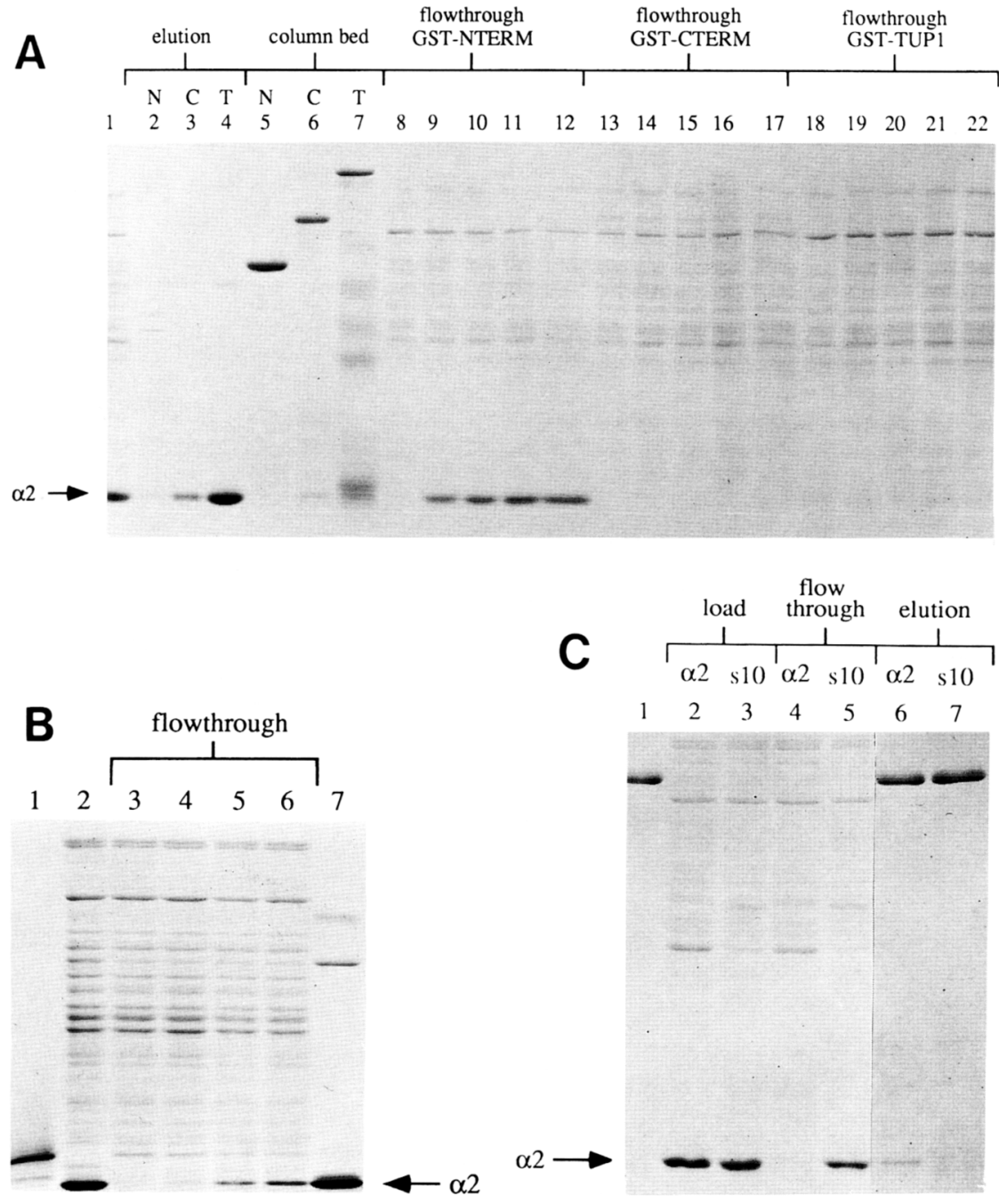

Figure 5. $\alpha 2$ binds to a single WD repeat of Tup1. (A) Coomassie blue-stained SDS gel showing the results of passing a bacterial extract containing $\alpha 2$ (lane 1 ) over columns bearing purified GST-NTERM (lane 5), GST-CTERM (lane 6), and GST-TUP1 (lane 7). Flowthrough fractions from each column are as indicated. The columns were eluted with $1 \mathrm{M}$ salt. The peak fractions were pooled and are shown in lanes 2-4 (N, C, and T, indicate GST-NTERM, GST-CTERM, and GST-TUP1, respectively). $\alpha 2$ is indicated $(\rightarrow) .(B)$ Coomassie blue-stained SDS gel containing the results from passing a bacterial extract containing $\alpha 2$ over a column bearing GSTWD2. (Lane 1) A sample of the column bed; (lane 2) a portion of the $\alpha 2$ extract; (lanes 3-6) fractions of the column flowthrough; (lane 7) a sample of the high salt eluate from the column. $(C)$ Bacterial extracts containing either wild-type $\alpha 2$ (lane 2) or mutant $\alpha 2^{\text {Ser10 }}$ (lane 3) were passed over columns bearing GSTCTERM Tupl (lane 1). Mutant $\alpha 2$ flowed through the column (lane 5), whereas wild-type $\alpha 2$ was retained. The columns were eluted with glutathione, displacing GST-CTERM and $\alpha 2$ from the column loaded with wild-type $\alpha 2$, but only GSTCTERM from the column loaded with mutant $\alpha 2$ (lanes 6 and 7, respectively).
Tupl WD repeats (Fig. 4B). If this WD repeat-like portion of middle region of Tup 1 is responsible for $\alpha 2$ binding, then a single WD repeat should be sufficient to bind $\alpha 2$. To test this idea, amino acids 439-473, comprising the second Tup1 WD repeat, were fused to the GST domain creating GST-WD2 (see Fig. 4A). A column bearing GST-WD2 (Fig. 5B, lane 1) specifically retained $\alpha 2$, which was eluted from the column with high salt (lane 7). This result indicates that a single WD repeat of Tup1 is sufficient for binding $\alpha 2$.

\section{Amino-terminal $\alpha 2$ mutant fails to bind to Tup1}

The behavior of $\alpha 2$ repression-defective mutants discussed above suggested that the amino-terminal region of $\alpha 2$ may be required for binding Tup1. To test this model we made extracts from $E$. coli expressing the $\alpha 2^{\text {Ser10 }}$ mutant. Extracts containing $\alpha 2^{\text {Ser } 10}$ or wild-type $\alpha 2$ were passed over columns bearing the GST-CTERM Tupl fusion protein. The results of this experiment are shown in Figure 5C. Lane 1 represents the GST-CTERM column bed. Lanes 2 and 3 are samples of the extracts containing the wild-type $\alpha 2$ protein and the $\alpha 2^{\text {Ser10 }} \mathrm{mu}$ tant, respectively. The wild-type $\alpha 2$ protein was retained on the column as indicated by the absence of the $\alpha 2$ in the column flowthrough (lane 4). In contrast, the $\alpha 2^{\text {Ser10 }}$ mutant protein appeared in the flowthrough (lane 5). The columns were washed and subsequently eluted with free glutathione, which displaces GST-CTERM protein and any protein bound to it from the glutathione-agarose bed. Elution of the column loaded with wild-type $\alpha 2$ displaced both $\alpha 2$ and GST-CTERM (lane 6), whereas elution of the column loaded with $\alpha 2^{\text {Ser10 }}$ yielded only the GST-CTERM protein (lane 7). These results indicate that the wild-type $\alpha 2$ amino terminus is required for Tupl binding. Consistent with this idea, a deletion mutant of $\alpha 2$ lacking amino acids $2-10\left(\alpha 2^{\Delta 2-10}\right)$ also failed to bind to a GST-CTERM Tupl column /data not shown). Curiously, when the same experiment is repeated with a column bearing the single WD repeat, $\alpha 2^{\Delta 2-10}$ bound as well as wild-type $\alpha 2$ (data not shown). Thus, the amino terminus of $\alpha 2$ is required for binding a 
portion of Tupl containing all seven WD repeats; it is not required to bind to WD2 in isolation. A possible explanation is that the WD repeat(s) of Tupl required for binding $\alpha 2$ are masked in some way, and the amino terminus of $\alpha 2$ is required to unmask these WD repeats allowing Tup 1 and $\alpha 2$ to associate.

\section{The carboxyl terminus of Tup1 is sufficient for $\alpha 2$-mediated repression in vivo}

Repression of the a-specific genes requires that Tup1 both bind to $\alpha 2$ and interfere with transcription. The affinity column experiments demonstrated that the carboxyl terminus of Tupl interacts with $\alpha 2$ in the absence of Ssn6. Next, we wished to determine whether a carboxy-fragment of Tupl is sufficient for in vivo repression as well. $\alpha$ cells lacking either Tupl or Ssn 6 are sterile, because of the derepression of the a-specific genes. If the carboxyl terminus of Tup 1 is capable of both binding $\alpha 2$ and repressing transcription in the absence of Ssn6, then expressing the carboxyl terminus in an $\alpha$ strain lacking both Tupl and Ssn 6 should restore repression of the a-specific genes and correct the mating defect. As shown in Figure 6, a MAT $\alpha$ tup $1 \Delta s s n 6 \Delta$ strain transformed with a vector plasmid is sterile, but the same strain transformed with a plasmid overexpressing either fulllength Tupl or Tup1(336-713) mates as an $\alpha$ cell, indicating that repression of the a-specific genes has been at least partially restored. Hence, a fragment of Tup1 consisting almost exclusively of WD repeats is capable of both interacting with $\alpha 2$ and bringing about repression. Furthermore, Ssn6 is not absolutely required for either function, as overexpression of Tupl partially compensates for a lack of Ssn6. Overexpression of Ssn6, in contrast, has no effect on the mating behavior of the $M A T \alpha$ tup1 $\Delta \operatorname{ssn} 6 \Delta$ strain (data not shown).

We wish to emphasize that suppression of the phenotypes of a tup1 $1 \Delta \operatorname{ssn} 6 \Delta$ strain by the fragment of Tup1

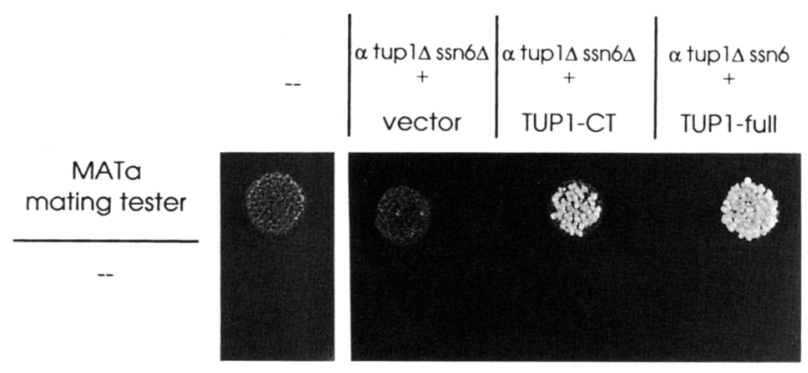

Figure 6. Overexpression of Tupl suppresses the mating defect of a $M A T \alpha \operatorname{ssn} \Delta t u p 1 \Delta$ strain. A MATa $\operatorname{ssn} 6 \Delta$ tup $1 \Delta$ strain was transformed with plasmids expressing no Tupl, the Tupl carboxyl terminus (CT), or full-length Tupl (full) from the GAL10 promoter. Transformants were mixed with a MATa tester strain (top) or no tester strain (bottom) and grown on a plate that selects for diploids resulting from conjugation. The unmated MATa tester strain is plated to the far left. Unmated transformants plated in the bottom row do not form a background patch because of their slow growth and clumpiness. containing only WD repeats is not complete. In addition to exhibiting $\alpha$-specific sterility, yeast strains lacking Ssn6 or Tupl are clumpy and slow growing, presumably because of the inappropriate expression of normally repressed genes. Overexpression of Tup1 does not correct the slow growth or clumpiness of the tup $1 \Delta \operatorname{ssn} 6 \Delta$ strain, indicating that the absence of Ssn 6 cannot be completely compensated for by increased levels of Tup1. Also, although overexpression of Tupl (336-713) provides sufficient repression of a-specific genes to suppress the mating defect of an $\alpha \operatorname{tup} 1 \Delta \operatorname{ssn} 6 \Delta$ strain, the level of repression of an $m f a 2: l a c Z$ reporter in these strains is quite weak; much stronger repression is observed when either Tupl(254-713) or full-length Tupl is overexpressed.

\section{Discussion}

\section{Tup1 interacts with a DNA-binding protein}

Although Ssn6 and Tup1 are required for the transcriptional repression of a wide variety of genes, neither Ssn6 nor Tup1 has been reported to bind DNA, nor does there appear to be any promoter element common to all sets of Ssn6/Tup1-repressed genes. Our present studies show that Tupl interacts directly with $\alpha 2$, a homeo domain protein that binds to sequences found upstream of the a-specific genes. The in vivo relevance of the in vitro interaction between Tupl and $\alpha 2$ is supported by our isolation of $\alpha 2$ repression-defective mutants that occupy the operator but fail to repress and by our observation that the strongest of these mutants does not bind Tupl in vitro. These results imply that $\alpha 2$ directs repression by interacting with Tupl and that the failure of the mutants to repress transcription is attributable to their inability to recruit Tupl to the operator.

We predict that Tupl also interacts with the DNAbinding proteins found upstream of other Ssn6/Tup1regulated genes, thus explaining how Ssn6 and Tup1 are able to inhibit expression of a wide variety of genes having no common upstream sequences. This arrangement of a transcriptional regulator influencing many diverse genes by interacting with a multitude of site-specific DNA-binding proteins has also been reported for the viral activator E1A, which interacts directly with various gene regulatory proteins that bind upstream of E1A-regulated genes (e.g., see Liu and Green 1994). Unlike E1A, which interacts directly with the DNA-binding domains of various transcriptional activators, Tupl requires a region of $\alpha 2$ outside of the DNA-binding domain. The lesions in three of the four repression-defective mutants that we have isolated lie in the extreme amino terminus of $\alpha 2$, indicating that this stretch of amino acids is important for interaction with Tupl.

\section{A single WD repeat is a protein-protein interaction domain}

The carboxyl terminus of Tupl contains seven copies of a repeating 40 amino acid motif known as the WD repeat. Originally identified in the $\beta$-subunit of the het- 
erotrimeric G protein transducin, the WD repeat has since been found in a wide variety of proteins. Because members of the WD family of proteins share no obvious functional properties and are often engaged in multisubunit complexes, it has been assumed that the WD repeat is a structural element involved in protein-protein interaction. This assumption is supported by several observations. First, proteins such as $\beta$-transducin and Sec13, which are known to interact biochemically with other proteins, consist mainly of WD repeats, suggesting that binding might occur through the repeats (for review, see Conklin and Bourne 1993; Salama et al. 1993). Second, antibodies raised to peptides within the repeats of $\beta$-transducin can inhibit its ability to interact with the transducin $\alpha$ subunit (Murakami et al. 1992). Third, Gpal and Ste 4 , the $\alpha$ and $\beta$ subunits of a yeast G protein, interact in vivo in the two-hybrid fusion assay; this interaction is disrupted by mutations in the second WD repeat of Ste4 (Clark et al. 1993; Whiteway et al. 1994). In this study we have shown directly that a single WD repeat of Tupl will bind to $\alpha 2$ and can therefore function as a discrete unit.

The ability of an isolated WD repeat to mediate protein binding raises the question of why WD repeats tend to be found in iterated arrays. One possibility is that the repeats are functionally redundant. Tup 1, for example, probably has at least two WD repeats capable of binding $\alpha 2$ if WD1 is responsible for the binding of the middle region to $\alpha 2$. The presence of more than one $\alpha 2$-binding WD repeat might allow full-length Tupl to interact with more than one domain or molecule of $\alpha 2$ and thus strengthen overall binding. Another possibility is that interactions between the WD repeats themselves influence the binding properties of the protein as a whole. A fragment of Tupl containing all seven WD repeats binds to wild-type $\alpha 2$ but not to an $\alpha 2$ negative control mutant; a single WD repeat binds to both wild-type and mutant $\alpha 2$. Apparently the presence of other WD repeats somehow confers specificity upon the binding of an individual repeat to $\alpha 2$. Finally, it is possible that different WD repeats bind different proteins. In addition to binding to $\alpha 2$, Tup1 presumably interacts with various DNAbinding proteins found upstream of other Ssn6/Tup1repressed genes as well as with other components of the repression machinery (see below). Each of these interactions could, in principle, be carried out by a different WD repeat. The presence of multiple repeats might allow WD proteins in general to interact with several proteins at once and to direct the assembly of a variety of multiprotein complexes.

The WD repeats of Tup1 bind $\alpha 2$ and partially repress transcription in vivo

Because $\alpha$ cells lacking either Ssn 6 or Tup1 aberrantly express their a-specific genes, it was thought that both proteins were necessary for $\alpha 2$-mediated repression. Surprisingly, we have found that overexpression of the carboxyl terminus of Tup1 allows partial repression of the a-specific genes in a strain lacking Ssn6, indicating that the WD repeats of Tup1 can mediate both binding to $\alpha 2$ and partial repression of transcription and that Ssn6 is not absolutely required for either of these activities. Hence, it appears that $\alpha 2$-directed repression involves a complex of $\alpha 2$, Tup1, and Ssn6, in which $\alpha 2$ binds DNA, Tup1 both binds $\alpha 2$ and interferes with transcription, and Ssn6 plays a peripheral role, perhaps serving to stabilize the Tup $1 / \alpha 2$ complex (Fig. 7 ).

The inability of Tupl overexpression to correct all of the defects of a tup $1 \Delta \operatorname{ssn} 6 \Delta$ strain indicates that $\operatorname{Ssn} 6$ is required for repression of some sets of genes even in the presence of excess Tup1. One possible explanation for this observation is that the interaction between Tupl and $\alpha 2$ is stronger than the interaction between Tup1 and other DNA-binding repressors and that we cannot achieve sufficiently high levels of Tupl in vivo to drive formation of the other complexes in the absence of Ssn6. Alternatively, the Ssn6-Tup1 complex might interact differently with the individual DNA-binding proteins that mediate repression of the various repressed gene sets. This latter explanation is supported by the observation that a fragment of Tupl lacking WD repeats will partially repress a hypoxic gene and a glucose-repressed gene but not an $\alpha 2$-regulated gene in the presence of Ssn 6 (Tzamarias and Struhl 1994; K. Komachi and A.D. Johnson, unpubl.). These results are not necessarily contradictory, given that Tupl appears to have two repression domains (Tzamarias and Struhl 1994): one in the amino terminus, which also contains an Ssn6-binding domain; and one in the carboxyl terminus, in a region overlapping with the first WD repeat. It is possible that the Ssn6-Tupl complex interacts with Roxl and Migl mainly through $S s n 6$ but with $\alpha 2$ mainly through Tupl. Thus, the amino terminus of Tupl could repress transcription of the hypoxic and glucose-repressed genes by tethering the amino-terminal repression domain to Rox1 and Mig1 via Ssn6; likewise, the carboxyl terminus of Tupl could repress transcription of the a-specific genes by recruitment of the carboxy-terminal repression do-

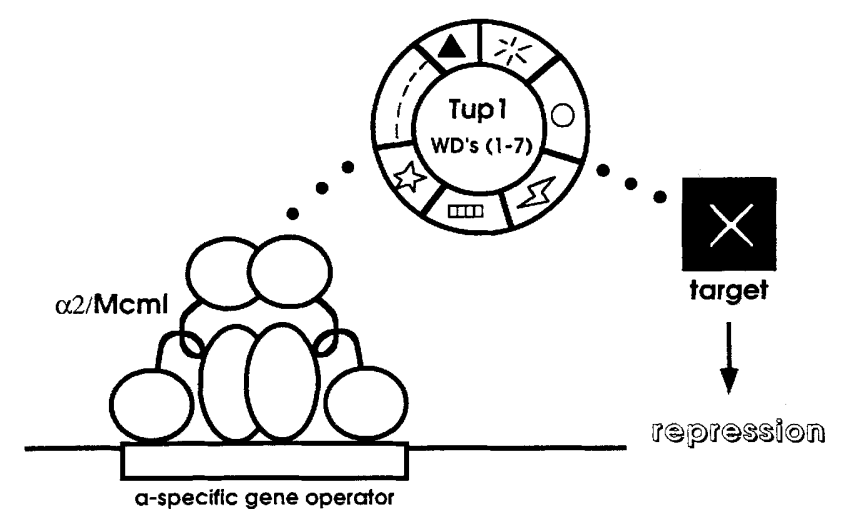

Figure 7. Model for $\alpha 2$ repression. Tupl is recruited to the a-specific genes by binding to $\alpha 2$ and represses transcription by interacting with a downstream target. The WD repeats (represented by the different symbols) mediate both of these interactions, which can occur in the absence of Ssn6. 
main via a direct interaction between Tupl and $\alpha 2$. Complete repression of all sets of Ssn6-Tup1-regulated genes, however, would require both full-length Tup1 and Ssn6.

\section{Possible targets of Tup1 repression}

Although it is formally possible that Tupl represses merely by binding to $\alpha 2$ and providing some sort of steric block to transcription, we believe that Tup1 interferes with transcription by interacting with a downstream target for the following reasons. First, mutations in genes other than SSN6 and TUP1 disrupt $\alpha 2$-mediated repression and cause pleiotropic phenotypes similar to those engendered by disrupting SSN6 or TUP1 (M. Wahi and A. Johnson, pers. comm.). The products of these ARE (alpha2 repression) genes represent possible downstream targets of Tup1. Second, there exist dominant alleles of TUP1 whose mutations map to WD repeats other than those thought to bind $\alpha 2$ (K. Komachi and A.D. Johnson, unpubl.). Such mutants might be dominant because they fail to interact with the downstream target but are able to bind $\alpha 2$ and displace wild-type Tup1. Finally, deletion analysis by Tzamarias and Struhl (1994) has identified at least two regions of Tupl that are capable of repressing transcription from a LexA operator when fused to LexA and may interact with downstream targets.

Although the ultimate target of Tupl repression is the transcription machinery, the direct downstream target remains a mystery. One possibility is that Tupl interacts with nucleosomes or some component of chromatin, as $\alpha 2$ has been shown to position nucleosomes in an Ssn6/ Tup1-dependent manner, and correlations have been made between nucleosome positioning and repression (Roth et al. 1990; Cooper et al. 1994). However, it is unlikely that nucleosomes are the sole target because mutations in histone $\mathrm{H} 4$ that disrupt nucleosome positioning by $\alpha 2$ cause only slight derepression of the a-specific genes (Roth et al. 1992). Furthermore, $\alpha 2$ can direct Tupl-dependent repression of basal transcription in an in vitro system that presumably lacks nucleosomes, suggesting that another target of Tupl might be RNA polymerase and its entourage of initiation factors (Herschbach et al. 1994). Given that each WD repeat theoretically allows interaction with at least one other protein, the ability to bind multiple targets may be a general characteristic of WD proteins. $\beta$-Transducin, for example, is thought to act in signal transduction by influencing a variety of downstream effectors, including $\beta$-adrenergic receptor kinase, phospholipases $\mathrm{A}_{2}$ and $\mathrm{C}$, and adenyl cyclase (for review, see Clapham and Neer 1993). Likewise, Tupl might repress transcription by interacting with a number of different proteins, such as histones, the $A R E$ gene products, or components of the general transcription machinery.

\section{Materials and methods}

Plasmids and strains

Plasmid pAV101 was constructed by Andrew Vershon (Waksman Institute, Rutgers, Piscataway, NJ) and contains the Hin-
dIII-HindIII MAT $\alpha$ fragment (Astell et al. 1981) into which a $B g I I I$ site has been engineered at the codon for the eighth amino acid of $\alpha 2$ and in which the HpaI site immediately downstream of $\alpha 2$ has been replaced by a BamHI site. Plasmid pKK63 was constructed from pAV101 by removing the $0.7-\mathrm{kb}$ NdeI fragment containing $\alpha 1$ and inserting the resulting $3.6-\mathrm{kb}$ HindIII fragment into the HindIII site of YEp13 (Broach et al. 1979).

Plasmid pKK68 was constructed by inserting the center-substituted operator (Keleher et al. 1988; see Fig. 4) into the XhoI site of a version of pLG $\Delta S S$ (Johnson and Herskowitz 1985) from which the $2 \mu$ sequences have been removed. Yeast strain KKYd25 was constructed by integrating pKK68 at the URA3 locus of KT23ax8 (mat $\Delta$ trp1 leu2 ura3 his4) (Tatchell et al. 1981; Siliciano and Tatchell 1984). Single-copy integration was confirmed by DNA-DNA hybridization.

Unless noted otherwise, all yeast strains used were constructed in the EG123 background (Astell et al. 1981). The $\alpha$ mfa2:lacZ fusion strain used was SM1196 (MAT $\mathrm{mfa2:1acZ}$ trp1 leu2 ura3 his4) (Hall and Johnson 1987). KKY122 was constructed by replacing MATa2 of SM1196 with URA3. All mutant $\alpha 2 m f a 2:$ lac $Z$ strains were constructed by cotransforming KKY122 with YEp13 and a HindIII-NdeI fragment containing the mutant $M A T \alpha 2$, selecting for growth on medium lacking leucine and subsequently selecting for loss of the URA3 marker on medium containing 5-fluoro-orotic acid. Integration at $M A T$ was determined by DNA-DNA hybridization.

The TUP1 and SSN6 high-copy plasmids used were pFW28 and pLN113-3, respectively (Schultz and Carlson 1987; Williams and Trumbly 1990). Plasmid pKK371 was constructed by inserting the SphI fragment containing SSN6 from pLN113-3 into the SphI site of pFW28, creating a high-copy plasmid containing both TUP1 and SSN6.

The GST-CTERM expression vector was constructed by ligating the BamHI fragment from plasmid pFW28 (Williams and Trumbly 1990) containing a portion of the TUP1 seqence into pGEX-2T (Smith and Johnson 1988). The remaining GST-fusion expression vectors were constructed by amplification of the appropriate TUP1 seqences with the polymerase chain reaction (PCR). Oligonucleotides $\left(5^{\prime}\right.$ and $\left.3^{\prime}\right)$ containing restriction sites were utilized to facilitate cloning into vectors $\mathrm{pGEX}-3 \mathrm{X}$ or pGEX-2T (Smith and Johnson 1988).

Plasmids pAV99 (Mak and Johnson 1993) and pKK211 were used to create $E$. coli expression vectors for $\alpha 2$ and $\alpha 2^{\text {Ser10 }}$, respectively. Plasmid pKK211 was constructed by replacing the BglII-BamHI fragment of pAV99 with the BglII-BamHI fragment of pKK99, the Ser-10 mutant version of pKK63. For overexpression in E. coli, the 1.0-kb BamHI fragment was removed from downstream of the $\alpha 2^{\text {Ser10 }}$ coding sequence, and the resulting plasmid was transformed into an $E$. coli strain containing an $\mathrm{F}^{\prime} l a c I^{\mathrm{Q} 1}$.

Plasmids for expressing full-length Tupl or the carboxyl terminus of Tup1 in yeast were constructed using pSJ1 (Herschbach et al. 1994), which contains the GAL10 promoter upstream of a polylinker. Plasmid $\mathrm{p} \Delta \mathrm{SI}$ was constructed by Andrew Vershon by deleting the XhoI-Sall fragment containing the translational start of pSJ1. Plasmid pKK391 was constructed by replacing the BamHI-HindIII fragment of $\mathrm{p} \Delta \mathrm{SI}$ with a PCR fragment containing the entire coding sequence of TUP1. Plasmid pKK462 was constructed by replacing the BamHI-HindIII fragment of pSI1 with a PCR fragment containing the coding sequence for amino acids 336-713 of TUP1.

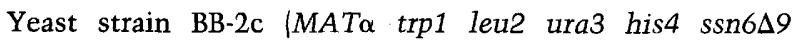
tup1 $\triangle:: L E U 2$ ) was provided by Burkhard Braun (University of California, San Francisco). KKY144 was constructed by replacing the tup1 $\triangle:: L E U 2$ allele of BB-2c with an unmarked TUP1 deletion and transforming the resulting strain with pAS107, an 
integrating GAL2-bearing plasmid provided by Anita Sil (University of California, San Francisco). The unmarked TUP1 deletion was introduced into BB-2c using plasmid pRT164 which contains a TUP1 deletion disrupted by URA3 flanked by his $G$ repeats (Alani et al. 1987); pRT164 was provided by Robert Trumbly (Medical College of Ohio, Toledo).

\section{Plasmid mutagenesis}

Mutagenesis of pKK63 by passage through a mutator strain of $E$. coli was achieved by transforming the plasmid into TAM12mutD5 (Scheuermann et al. 1983). A single transformed colony was isolated, picked, and grown to saturation in $50 \mathrm{ml}$ of LB medium plus $100 \mu \mathrm{g} / \mathrm{ml}$ of ampicillin, and plasmid DNA was isolated from these cells. Hydroxylamine mutagenesis of pKK63 was performed as described previously (Nelson et al. 1983 ) except that the DNA was incubated in hydroxylamine at $65^{\circ} \mathrm{C}$ for $90 \mathrm{~min}$ and the hydroxylamine was removed by passing the sample over a P10 resin spin column. Mutagenized plasmid DNA was used to transform JA194, a leuB $B^{-}$strain of $E$. coli whose inability to grow on leucine can be complemented by the S. cerevisiae LEU2 gene. Transformed JA194 colonies able to grow on LB plus $50 \mathrm{mg} / \mathrm{ml}$ of ampicillin but unable to grow on media lacking leucine were found at an approximate frequency of $10^{-4}$.

\section{Mutant screen and yeast plasmid isolation}

KKYd25 was transformed with mutagenized plasmid DNA by the lithium acetate method (Ito et al. 1983) and plated at a density of $\sim 500$ colonies per plate on plates lacking leucine and uracil (-Ura-Leu plates). Transformants were replica plated onto nitrocellulose filters on - Ura-Leu plates and grown for 12 $\mathrm{hr}$ at $30^{\circ} \mathrm{C}$. The colonies were scored for $\beta$-galactosidase production by immersing the filter in liquid nitrogen for $20 \mathrm{sec}$, placing the filter on a disc of Whatman $3 \mathrm{MM}$ paper in a petri dish containing $2.2 \mathrm{ml}$ of $0.3 \mu \mathrm{g} / \mathrm{ml} \mathrm{5}$-bromo-4-chloroindolyl- $\beta$-Dgalactopyranoside (Xgal) in Z buffer (Miller 1972), and incubating the filter for $10 \mathrm{hr}$ at $30^{\circ} \mathrm{C}$.

Potential positives were picked from the original transformation plate, streaked for single colonies, and retested for blueness by the filter assay. Mutant plasmids were isolated from positive colonies as described in Schena et al. (1989). Yeast plasmids were transformed into the E. coli strain $\mathrm{HBl} 101$ by the $\mathrm{CaCl}_{2}$ method.

\section{Liquid $\beta$-galactosidase assays}

$\beta$-Galactosidase assays were performed as described (Miller 1972 ), except that yeast cells were permeabilized with $0.0025 \%$ SDS and $5 \%$ chloroform, the assays were performed at $25^{\circ} \mathrm{C}$, and the cell debris was removed by centrifugation prior to reading the $\mathrm{OD}_{420}$ of the sample, thus eliminating the need to correct for light scatter. Activities are reported in Miller units.

\section{Purification of GST-fusion proteins}

GST-fusion protein expression vectors were transformed into E. coli, and cells carrying expression vectors were grown to saturation in $300 \mathrm{ml}$ of $\mathrm{LB}$ medium containing $100 \mu \mathrm{g} / \mathrm{ml}$ of ampicillin. This culture was then used to inoculate 3 liters of $2 \times$ LB containing $100 \mu \mathrm{g} / \mathrm{ml}$ of ampicillin. Cells were grown to an optical density of $\sim 0.8$. IPTG was added to $0.1 \mathrm{~mm}$. Cells were grown for $3 \mathrm{hr}$ and subsequently harvested by centrifugation. Cells were washed once in ice-cold PBS [140 mM Na $2 \mathrm{HPO}_{4}, 1.8$ $\mathrm{mM} \mathrm{KH}_{2} \mathrm{PO}_{4}$ (pH 7.2), $138 \mathrm{~mm} \mathrm{NaCl}, 2.7 \mathrm{~mm} \mathrm{KCl}$ ) and frozen in liquid nitrogen. Cells were lysed by the addition of 5 volumes of PBS containing $1 \mathrm{mM}$ EGTA, $1 \mathrm{~mm}$ EDTA, $1 \mathrm{~mm}$ PMSF, and 200 $\mu \mathrm{g} / \mathrm{ml}$ of lysozyme. Cells were stirred for $30 \mathrm{~min}$ to break up the pellet. Lysis was completed with sonication or several minutes. $\mathrm{KCl}$ and DTT were added to $0.3 \mathrm{M}$ and $15 \mathrm{~mm}$, respectively. Extracts were then centrifuged at $100,000 \mathrm{~g}$ for $1 \mathrm{hr}$ prior to loading over a $6-\mathrm{ml}$ glutathione-agarose column at $40 \mathrm{ml} / \mathrm{hr}$. The columns were then washed with PBS containing $0.3 \mathrm{M} \mathrm{KCl}$ and $1 \mathrm{mM}$ DTT at a flow rate of $60 \mathrm{ml} / \mathrm{hr}$ until no proteins could be detected in the flowthrough. The columns were eluted with $50 \mathrm{~mm}$ Tris ( $\mathrm{pH} 8.0), 0.3 \mathrm{M} \mathrm{KCl}$, and $5 \mathrm{~mm}$ glutathione. Protein was detected by Bradford assay (Bradford 1976). Peak fractions were pooled and dialyzed into $50 \mathrm{mM}$ HEPES (pH 7.6), $0.25 \mathrm{M}$ $\mathrm{KCl}, 30 \%$ glycerol, $1 \mathrm{~mm}$ EGTA, $1 \mathrm{~mm} \mathrm{MgCl}_{2}$, and $1 \mathrm{mM}$ DTT. Protein yields varied between 5 and $50 \mathrm{mg}$, depending on the particular fusion protein. Proteins were frozen in liquid nitrogen and stored at $-75^{\circ} \mathrm{C}$.

\section{$\alpha 2$ and $\alpha 2^{\text {Ser10 }}$ extracts}

E. coli extracts containing $\alpha 2$ or $\alpha 2^{\text {Ser10 }}$ were prepared as described in Sauer et al. (1988), except that the extracts were prepared from cells grown at $37^{\circ} \mathrm{C}$ and were purified no further than the ammonium sulfate precipitation step. The ammonium sulfate pellet was resuspended in $U$ buffer $(50 \mathrm{~mm}$ Tris $(\mathrm{pH} 8.0), 1$ $\mathrm{mM}$ EDTA, $10 \mathrm{mM}$ 2-mercaptoethanol, $5 \mathrm{~m}$ ureal, dialyzed against $U$ buffer, and centrifuged at $10,000 \mathrm{rpm}$ in an SS34 rotor for $30 \mathrm{~min}$. The supernatant was then dialyzed against $\mathrm{S}+500$ buffer [ $500 \mathrm{~mm} \mathrm{NaCl}, 50 \mathrm{~mm}$ Tris- $\mathrm{HCl}$ (pH 8.0), 1 mM EDTA, 10 $\mathrm{mm} 2$-mercaptoethanol] and centrifuged at $10,000 \mathrm{rpm}$ in an SS34 rotor for $30 \mathrm{~min}$. Extracts were stored at $-75^{\circ} \mathrm{C}$ in $\mathrm{S}+500$ buffer.

\section{Column chromatography}

GST-fusion proteins were immoblized on glutathione-agarose (Sigma) by incubating overnight in binding buffer $250 \mathrm{mM} \mathrm{KCl}$, $50 \mathrm{~mm}$ HEPES at $\mathrm{pH} 7.6,10 \%$ glycerol, $2 \mathrm{~mm}$ DTT, $1 \mathrm{~mm}$ $\mathrm{MgCl}_{2}$ ). Columns were then constructed containing $0.5 \mathrm{ml}$ of glutathione-agarose bound to $\sim 0.5 \mathrm{mg}$ of GST-fusion protein. The columns were pre-eluted with $2 \mathrm{ml}$ of elution buffer $(1 \mathrm{M}$ $\mathrm{NaCl}, 2 \mathrm{~mm}$ DTT, $50 \mathrm{~mm}$ HEPES at $\mathrm{pH} 7.6,2 \mathrm{~mm}$ EDTA) and equlibrated with $4 \mathrm{ml}$ of wash buffer $(30-50 \mathrm{~mm} \mathrm{NaCl}, 50 \mathrm{~mm}$ HEPES at $\mathrm{pH} 7.6,10 \%$ glycerol, $2 \mathrm{mM}$ DTT, $1 \mathrm{~mm} \mathrm{MgCl}_{2}$ ).

Bacterial extracts containing $\alpha 2$ or derivatives were diluted to a final salt concentration of $30-50 \mathrm{~mm} \mathrm{NaCl}$ in $50 \mathrm{~mm}$ HEPES at $\mathrm{pH}$ 7.6, $2 \mathrm{mM}$ DTT, $1 \mathrm{mM} \mathrm{MgCl}$, $0.1 \mathrm{mM}$ AEBSF (Calbiochem). Diluted extracts were centrifuged at $100,000 \mathrm{~g}$ for $1 \mathrm{hr}$ prior to loading over columns. Extract $(4 \mathrm{ml}$ ) was loaded at $1.5 \mathrm{ml} / \mathrm{hr}$ on columns. Fractions $(0.5 \mathrm{ml})$ were collected. The columns were washed with 2 of $\mathrm{ml}$ wash buffer then eluted with elution buffer. Peak fractions were identified by Bradford assays and pooled. Pooled elution fractions and flowthrough fractions were then precipitated with $10 \%$ trichloroacetic acid. Protein pellets were resuspended in SDS sample buffer and loaded onto $12 \%$ or $14 \%$ SDS-polyacrylamide gels for eletrophoresis. Gels were then stained with Coomassie blue.

\section{Mating tests}

Transformed strains and a MATa lys1 tester strain were grown to saturation in liquid media containing $2 \%$ galactose and lacking leucine (SGAL - Leu). The transformants were mixed with the tester at a ratio of 10:1 (transformant/tester), spotted onto SGAL - Leu plates, and incubated at $30^{\circ} \mathrm{C}$ for $24 \mathrm{hr}$. The grown 
patches were then replica plated onto minimal plates and incubated at $30^{\circ} \mathrm{C}$ for $24 \mathrm{hr}$ to select for diploids.

\section{Acknowledgments}

We thank Burkhard Braun, Cynthia Keleher, Robert Trumbly, and Madhu Wahi for communication of results prior to publication. We are particularly grateful to $B$. Braun and $M$. Wahi for sharing the observation that Tupl overexpression suppresses the mating defect caused by an SSN6 deletion and point mutation, respectively. We thank Doug Bob Kellogg for valuable advice and technical assistance with the GST protein purification; Anita Sil, Robert Trumbly, and Andrew Vershon for plasmids; B. Braun for yeast strains; Andrew W. Murray for prompt and perspicacious comments on the manuscript; Henry Bourne and members of his laboratory for useful discussions; Rebecca Smith for help with Figure 4; members of the Johnson laboratory, past and present, for advice, tolerance and constructive confabulation. This work was supported by a grant from the National Institutes of Health (NIH) to A.D.J. K.K. was supported in part by a National Science Foundation predoctoral fellowship and by a training grant from the NIH to the Department of Biochemistry and Biophysics at the University of California, San Francisco.

The publication costs of this article were defrayed in part by payment of page charges. This article must therefore be hereby marked "advertisement" in accordance with 18 USC section 1734 solely to indicate this fact.

\section{Note added in proof}

After this manuscript was accepted for publication, Elizabeth Reisinger and Cynthia Wolberger (Johns Hopkins University School of Medicine, Baltimore, MD) alerted us to a mutation present in our GST-WD2 expression plasmid. The mutation changes the TGG coding for amino acid 470 of Tupl to TGC, resulting in the substitution of cysteine for tryptophan at that position. This change bears only on the experiment shown in Figure 5B and summarized in Figure 4A, line 6, and may affect its interpretation. We apologize for this mistake and are now repeating the relevant experiment using a construct with the wild-type sequence.

\section{References}

Alani, E., L. Cao, and N. Kleckner. 1987. A method for gene disruption that allows repeated use of $U R A 3$ selection in the construction of multiply disrupted yeast strains. Genetics 116: 541-545.

Astell, C.R., L. Ahlstrom-Jonasson, M. Smith, K. Tatchell, K.A. Nasmyth, and B.D. Hall. 1981. The sequence of the DNAs coding for the mating-type loci of Saccharomyces cerevisiae. Cell 27: 15-23.

Balasubramanian, B., C.V. Lowry, and R.S. Zitomer. 1993. The ROX1 repressor of Saccharomyces cerevisiae hypoxic genes is a specific DNA-binding protein with a high-mobilitygroup motif. Mol. Cell. Biol. 13: 6071-6078.

Bender, A. and G.F. Sprague. 1987. MAT $\alpha$ l protein, a yeast transcription activator, binds synergistically with a second protein to a set of cell-type-specific genes. Cell 50: 681-691.

Bradford, M. 1976. A rapid and sensitive method for the quantitation of microgram quantities of protein utilizing the principle of protein-dye binding. Anal. Biochem. 72: 248254.

Broach, J.R., J.N. Strathern, and J.B. Hicks. 1979. Transformation in yeast: Development of a hybrid cloning vector and isolation of the CAN1 gene. Gene 8: 121-133.
Clapham, D.E. and E.J. Neer. 1993. New roles for G protein $\beta-\gamma$ dimers in transmembrane signalling. Nature 365: 403-406.

Clark, K.L., D. Dignard, D.Y. Thomas, and M. Whiteway. 1993. Interactions among the subunits of the $\mathrm{G}$ protein involved in Saccharomyces cerevisiae mating. Mol. Cell. Biol. 13: 1-8.

Conklin, B.R. and H.R. Bourne. 1993. Structural elements of G $\alpha$ subunits that interact with $G \beta \gamma$, receptors and effectors. Cell 73: 631-641.

Cooper, J.P., S.Y. Roth, and R.T. Simpson. 1994. The global transcriptional regulators, SSN6 and TUP1, play distinct roles in the establishment of a repressive chromatin structure. Genes \& Dev. 8: 1400-1410.

Duronio, R.J., J.I. Gordon, and M.S. Boguski. 1992. Comparative analysis of the $\beta$ transducin family with identification of several new members including $P W P 1$, a nonessential gene of Saccharomyces cerevisiae that is divergently transcribed from NMT1. Proteins 13: 41-56.

Elledge, S.J., Z. Zhou, J.B. Allen, and T.A. Navas. 1993. DNA damage and cell cycle regulation of ribonucleotide reductase. BioEssays 15: 333-339.

Fong, H.K.W., J.B. Hurley, R.S. Hopkins, R. Miake-Lye, M.S. Johnson, R.F. Doolittle, and M. Simon. 1986. Repetitive segmental structure of the transducin $\beta$-subunit: Homology with the CDC4 gene and identification of related mRNAs. Proc. Natl. Acad. Sci. 83: 2162-2166.

Hall, M.N. and A.D. Johnson. 1987. Homeo domain of the yeast repressor $\alpha 2$ is a sequence-specific DNA binding domain but is not sufficient for repression. Science 237: 1007-1012.

Herschbach, B.M., M.B. Arnaud, and A.D. Johnson. 1994. Transcriptional repression directed by the yeast $\alpha 2$ protein in vitro. Nature 370: 309-311.

Ito, H., Y. Fukuda, K. Murata, and A. Kimura. 1983. Transformation of intact yeast cells treated with alkali cations. $J$. Bacteriol. 153: 163-168.

Johnson, A.D. 1992. A combinatorial regulatory circuit in budding yeast. In Transcriptional regulation (ed. S.L. McKnight and K.R. Yamamotol, pp. 975-1006. Cold Spring Harbor Laboratry Press, Cold Spring Harbor, New York.

Johnson, A.D. and I. Herskowitz. 1985. A repressor (MAT $\alpha 2$ product) and its operator control expression of a set of cell type specific genes in yeast. Cell 42: 237-247.

Keleher, C.A., C. Goutte, and A.D. Johnson. 1988. The yeast cell-type-specific repressor $\alpha 2$ acts cooperatively with a noncell-type-specific protein. Cell 53: 927-936.

Keleher, C.A., S. Passmore, and A.D. Johnson. 1989. Repressor $\alpha 2$ binds to its operator cooperatively with yeast protein Mcml. Mol. Cell. Biol. 9: 5228-5230.

Keleher, C.A., M.J. Redd, J. Schultz, M. Carlson, and A.D. Johnson. 1992. Ssn6-Tupl is a general repressor of transcription in yeast. Cell 68: 708-719.

Liu, F. and M.R. Green. 1994. Promoter targeting by adenovirus Ela through interaction with different cellular DNA-binding domains. Nature 368: 520-525.

MacKay, V.L., S.K. Welch, M.Y. Insley, T.R. Manney, J. Holly, G.C. Saari, and M.L. Parker. 1988. The Saccharomyces cerevisiae $B A R 1$ gene encodes an exported protein with homology to pepsin. Proc. Natl. Acad. Sci. 85: 55-59.

Mak, A. and A.D. Johnson. 1993. The carboxy-terminal tail of the homeo domain protein $\alpha 2$ is required for function with a second homeo domain protein. Genes \& Dev. 7: 1862-1870.

McGrath, J.P. and A.E. Varshavsky. 1989. The yeast STE6 gene encodes a homolog of the mammalian multi-drug resistance P-glycoprotein. Nature 340: 400-404.

Miller, J.H. 1972. Experiments in molecular genetics. Cold Spring Harbor Laboratory, Cold Spring Harbor, New York.

Mukai, Y., S. Harashima, and Y. Oshima. 1991. AAR1/TUP1 
protein, with a structure similar to that of the $\beta$ subunit of $G$ proteins, is required for a $1-\alpha 2$ and $\alpha 2$ repression in cell type control of Saccharomyces cerevisiae. Mol. Cell. Biol. 11: 3773-3779.

Murakami, T., W. Simmons, and A. Spiegel. 1992. Site-specific antibodies directed against $G$ protein $\beta$ and $\gamma$ subunits: Effects on $\alpha$ and $\beta \gamma$ subunit interaction. Biochemistry 31: 2905-2911.

Nehlin, J.O. and H. Ronne. 1990. Yeast MIGI repressor is related to the mammalian early growth response and Wilms' tumour finger proteins. EMBO I. 9: 2891-2898.

Nelson, H.C.M., M.H. Hecht, and R.T. Sauer. 1983. Mutations defining the operator-binding sites of bacteriophage lambda repressor. Cold Spring Harbor Symp. Quant. Biol. 47: 441449.

Passmore, S., R. Elble, and B.K. Tye. 1989. A protein involved in minichromosome maintenance in yeast binds a transcriptional enhancer conserved in eukaryotes. Genes \& Dev. 3: 921-935.

Roth, S.Y., A. Dean, and R.T. Simpson. 1990. Yeast $\alpha 2$ repressor positions nucleosomes in TRP1/ARS1 chromatin. Mol. Cell. Biol. 10: 2247-2260.

Roth, S.Y., M. Shimizu, L. Johnson, M. Grunstein, and R.T. Simpson. 1992. Stable nucleosome positioning and complete repression by the yeast $\alpha 2$ repressor are disrupted by aminoterminal mutations in histone H4. Genes \& Dev. 6: 411425.

Salama, N.R., T. Yeung, and R.W. Schekman. 1993. The Sec13p complex and reconstitution of vesicle budding from the E.R. with purified cytosolic proteins. EMBO J. 12: 4073-4082.

Sauer, R.T., D.L. Smith, and A.D. Johnson. 1988. Flexibility of the yeast $\alpha 2$ repressor enables it to occupy the ends of its operator leaving the center free. Genes \& Dev. 2: 807-816.

Schena, M., L.P. Freedman, and K.R. Yamamoto. 1989. Mutations in the glucocorticoid receptor that distinguish interdigitated DNA binding and transcriptional enhancer activities. Genes \& Dev. 3: 1590-1601.

Scheuermann, R., S. Tam, P.M. Burgers, C. Lu, and H. Echols. 1983. Identification of the epsilon-subunit of Escherichia coli DNA polymerase III holoenzyme as the $d n a Q$ gene product: A fidelity subunit for DNA replication. Proc. Natl. Acad. Sci. 80: 7085-7089.

Schultz, J. and M. Carlson. 1987. Molecular analysis of SSN6, a gene functionally related to the SNF1 protein kinase of Saccharomyces cerevisiae. Mol. Cell. Biol. 7: 3637-3645.

Siliciano, P.G. and K. Tatchell. 1984. Transcription and regulatory signals at the mating type locus in yeast. Cell 37: 969978.

Smith, D.B. and K.S. Johnson. 1988. Single-step purification of polypeptides expressed in Escherichia coli as fusions with glutathione S-transferase. Gene 67: 31-40.

Sprague, G. 1991. Assay of yeast mating reaction. In Guide to yeast genetics and molecular biology (ed. C. Guthrie and G.R. Fink), pp. 77-93. Academic Press, San Diego, CA.

Tatchell, K., K.A. Nasmyth, B.D. Hall, C. Astell, and M. Smith. 1981. In vitro mutation analysis of the mating type locus in yeast. Cell 42: 237-247.

Trumbly, R.J. 1992. Glucose repression in the yeast Saccharomyces cerevisiae. Mol. Microbiol. 6: 15-21.

Tzamarias, D. and K. Struhl. 1994. Functional dissection of the yeast Cyc8-Tup1 transcriptional co-repressor complex. $\mathrm{Na}$ ture 369: 758-761.

van der Voorn, L. and H.L. Ploegh. 1992. The WD-40 repeat. FEBS Lett. 307: 131-134.

Whiteway, M., K.L. Clark, E. Leberer, D. Dignard, and D.Y Thomas. 1994. Genetic identification of residues involved in association of $\alpha$ and $\beta$ G-protein subunits. Mol. Cell. Biol. 14: 3223-3229.

Williams, F.E. and R.J. Trumbly. 1990. Characterization of TUP1, a mediator of glucose repression in Saccharomyces cerevisiae. Mol. Cell. Biol. 10: 6500-6511.

Williams, F.E., U. Varanasi, and R.J. Trumbly. 1991. The CYC8 and TUP1 proteins involved in glucose repression in Saccharomyces cerevisiae are associated in a protein complex. Mol. Cell. Biol. 11: 3307-3316.

Zitomer, R.S. and C.V. Lowry. 1992. Regulation of gene expression by oxygen in Saccharomyces cerevisiae. Microbiol. Rev. 56: 1-11. 


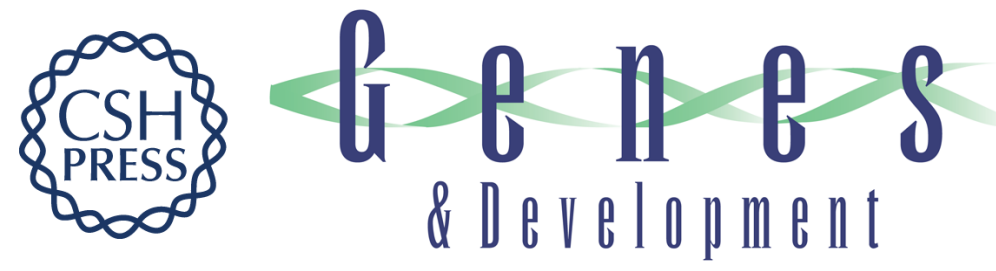

\section{The WD repeats of Tup1 interact with the homeo domain protein alpha 2.}

K Komachi, M J Redd and A D Johnson

Genes Dev. 1994, 8:

Access the most recent version at doi:10.1101/gad.8.23.2857

References This article cites 46 articles, 23 of which can be accessed free at:

http://genesdev.cshlp.org/content/8/23/2857.full.html\#ref-list-1

License

Email Alerting

Service

Receive free email alerts when new articles cite this article - sign up in the box at the top right corner of the article or click here.

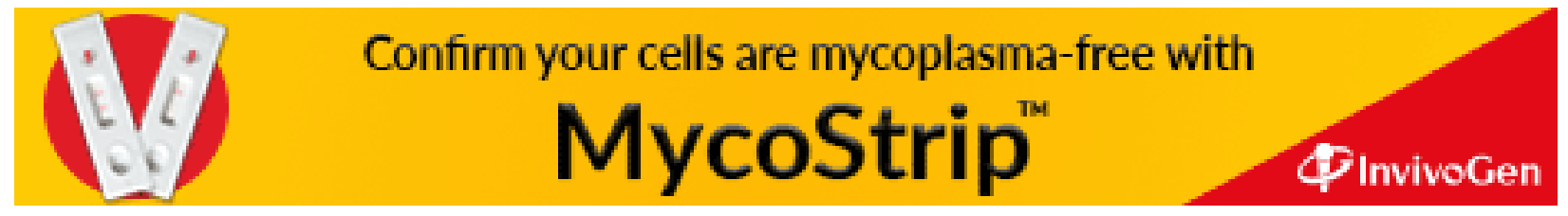

